\title{
Efek hipoglikemik tepung komposit (ubi jalar ungu, jagung kuning, dan kacang tunggak) pada tikus diabetes induksi streptozotocin
}

Hypoglycemic effect of composite flour (purple sweet potato, yellow corn, and cowpea) in streptozotocin-diabetic rats

\author{
Carolina Sisca Djunaidi ${ }^{1}$, Dian Rachmawanti Affandi ${ }^{1}$, Danar Praseptiangga ${ }^{1}$
}

\begin{abstract}
Background: The composite flour (50\% sweet potato, 30\% corn, and 20\% cowpea) had proven that it could substitute $100 \%$ wheat flour for biscuit making. Intake of antioxidants, dietary fiber, and protein, had been known to reduce plasma glucose level. Objective: To evaluate the effect of composite flour diet on plasma glucose levels, body weight and food consumption of streptozotocin (STZ)diabetic rats. Method: Thirty male Sprague-Dawley rats aged \pm 2 months ( \pm 200 grams), were divided into three groups of ten rats. They were (1) non-diabetic standard diet (ND-STD), (2) diabetic (65 $\mathrm{mg} / \mathrm{kg}$ of body weight by STZ induction) standard diet (D-STD), and (3) diabetic composite flour diet (1,5 g/100 g of body weight/day) (D-CFD), for 4 weeks, 3 days after STZ induction. The plasma glucose obtained from GOD-PAP method were determined before induction, after induction and every week during diet intervention. Results: Plasma glucose levels was significantly lower in D-CFD when compared with D-STD ( $<<0,05)$. The weight of D-STD was found to be significantly decreased as compared to ND-STD $(p<0,05)$. There were no changes in food consumption of ND-STD, D-STD and D-CFD ( $p<0,05)$. Conclusion: The composite flour could reduce plasma glucose level on diabetic rats and did not give negative effects on body weight and food consumption.
\end{abstract}

KEY WORDS: diabetic, streptozotocin-induced, composite flour, hypoglycemic effect

\begin{abstract}
ABSTRAK
Latar belakang: Tepung komposit (50\% ubi jalar ungu, 30\% jagung kuning, dan 20\% kacang tunggak) terbukti dapat menggantikan $100 \%$ terigu dalam pembuatan biskuit. Konsumsi antioksidan, serat, dan protein dapat menurunkan glukosa plasma. Tujuan: Mengevaluasi pengaruh diit tepung komposit pada glukosa plasma, berat badan, dan asupan pakan pada tikus diabetes induksi streptozotocin (STZ). Metode: 30 tikus Sprague-Dawley berumur \pm 2 bulan ( \pm 200 gram) dibagi menjadi 3 kelompok, yaitu (1) non-diabetes standar diit (ND-STD), (2) diabetes (diinduksi STZ $65 \mathrm{mg} / \mathrm{kg}$ berat badan) standar diit (D-STD), and (3) diabetes diit tepung komposit (1,5 g/100 g berat badan/hari) (D-CFD). Hasil: Glukosa plasma pada kelompok D-CFD secara signifikan lebih rendah daripada D-STD $(\mathrm{p}<0,05)$. Berat badan pada kelompok D-STD lebih rendah dibandingkan ND-STD ( $<<0,05)$. Tidak ada perbedaan konsumsi makanan yang bermakna pada kelompok ND-STD, D-STD, dan D-CFD (p<0,05). Simpulan: Tepung komposit dapat menurunkan glukosa plasma tikus diabetes induksi STZ tanpa berpengaruh negatif pada berat badan dan asupan pakan.
\end{abstract}

KATA KUNCI: diabetes, induksi streptozotocin, tepung komposit, efek hipoglikemik

\section{PENDAHULUAN}

Diabetes mellitus (DM) merupakan penyakit kronis yang melibatkan gangguan metabolisme karbohidrat, lemak, dan protein yang ditandai dengan naiknya kadar glukosa darah (hiperglikemik). Penyebabnya dapat berasal dari faktor keturunan dan pola hidup yang kurang sehat seperti makan tidak teratur dan berlebihan, mengonsumsi makanan cepat saji yang umumnya berlemak tinggi, kurangnya asupan antioksidan dan serat, serta kurangnya aktivitas fisik. Menurut World Health Organization (WHO) pada tahun 2010, terdapat penderita diabetes sekitar 285 juta orang di dunia dan 3,9 juta orang meninggal akibat diabetes setiap tahunnya (1).

Banyak penelitian telah dilakukan untuk menemukan formulasi tepung komposit yang dapat mensubstitusi tepung terigu dalam pembuatan biskuit (2-6). Salah satunya adalah formulasi 50\% tepung ubi jalar, 30\% tepung jagung, dan $20 \%$ tepung kacang tunggak, dapat menghasilkan biskuit yang mutu organoleptiknya hampir sama dengan biskuit dari ${ }^{1}$ Korespondensi: Program Studi Ilmu dan Teknologi Pangan, Universitas
Sebelas Maret Surakarta (UNS), Jl. Ir. Sutami 36A, Kentingan, Surakarta 57126; e-mail: ceesde.carolina.sisca@gmail.com 
$100 \%$ tepung terigu. Pencampuran 3 jenis tepung tersebut dilakukan agar kadar protein biskuit mencapai minimal 9\% sesuai syarat mutu biskuit berdasarkan Standar Nasional Indonesia (SNI) 01-2973-1992. Tepung ubi jalar ungu memiliki kadar protein hanya 3,15\% sehingga diperkaya dengan protein dari tepung jagung kuning sebesar 9,83\% dan protein dari tepung kacang tunggak 27,17\% (7-9). Dengan demikian, tepung komposit tersebut mengandung abu $2 \%$, lemak 2\%, dan 409 kalori sedangkan kandungan protein meningkat (6,76\%) yaitu dari 3,11\% menjadi 9,87\% (10).

Tepung ubi jalar ungu mengandung antosianin yang stabil dan serat total sebesar 4,45\% (11). Antosianin dalam ubi jalar ungu lebih stabil dibandingkan antosianin dari sumber pangan lainnya karena adanya acylating agents yang berupa senyawa cinnamic (caffeoyl, feruloyl, dan p-hydroxybenzoyl) (12). Tepung jagung kuning mengandung $9,83 \%$ protein dan $1,05 \%$ serat kasar $(8,13)$. Tepung kacang tunggak digunakan karena kandungan protein kacang tunggak sebesar 27,17\% dan kadar seratnya 26,18\% (9), lebih tinggi dibandingkan kandungan protein tepung terigu yang hanya $10,56 \%$ dan kadar seratnya $0,46 \%$ (14).

Senyawa fungsional dalam tepung komposit ini terdiri dari antosianin, serat pangan, dan protein yang dapat dijadikan alternatif diit bagi penderita diabetes. Penelitian ini dilakukan secara in vivo pada tikus putih jantan yang menderita diabetes akibat induksi streptozotocin (STZ). Senyawa tersebut tersusun dari glucosamine-nitrosourea yang bersifat sitotoksik, dapat merusak membran sel $\beta$ pankreas, merusak struktur deoxyribonucleic acid (DNA), meningkatkan radikal bebas dalam sel, serta mendukung pembentukan adenosine diphosphate ribose (ADPribosa), nicotinamide adenine dinucleotide (NAD), dan nicotinamide adenine dinucleotide phosphate (NADP). Hal tersebut mengakibatkan terhambatnya pembentukan dan sekresi insulin yang akhirnya menimbulkan diabetes (15). Oleh sebab itu, pada penelitian ini perlu dilakukan pengukuran kadar glukosa darah pada tikus DM yang diberi asupan tepung komposit, serta berat badan dan berat asupan pakan tikus.

\section{BAHAN DAN METODE}

Penelitian ini menggunakan metode kuantitatif dengan desain penelitian eksperimental laboratorium yang dilakukan dalam jangka waktu 3 bulan (Agustus - Oktober 2013). Proses pembuatan tepung komposit dilakukan di Laboratorium Rekayasa Proses Pengolahan Pangan dan Hasil Pertanian, Laboratorium Pangan dan Gizi, Prodi Ilmu dan Teknologi Pangan Fakultas Pertanian, Universitas Sebelas Maret (UNS) Surakarta. Bahan untuk pembuatan tepung ubi jalar ungu adalah ubi jalar lokal Tawangmangu varietas ungu yang didapat dari Pasar Tawangmangu, Karanganyar, Jawa Tengah. Bahan untuk pembuatan tepung jagung kuning adalah jagung kuning pipilan kering yang didapatkan di Pasar Gedhe Surakarta. Bahan untuk pembuatan tepung kacang tunggak adalah kacang tunggak yang diperoleh dari Pasar Legi Surakarta.

Pada percobaan in vivo digunakan tikus jantan jenis Sprague-Dawley (SD) berumur kurang lebih 2 bulan dengan berat kurang lebih $200 \mathrm{~g}$ (Laboratorium Penelitian dan Pengujian Terpadu, Universitas Gadjah Mada Yogyakarta) dan STZ (Nacalai Tesque, Jepang). Komposisi pakan standar tikus mengacu pada formula American Institute of Nutrition 1993 (AIN 1993) (16). Bahan analisis glukosa darah tikus adalah kit reagen GOD-PAP (DiaSys). Pemberian diit tepung komposit (ubi jalar ungu, jagung kuning, dan kacang tunggak) pada tikus diabetes induksi STZ dan analisis glukosa darah dilakukan di Laboratorium Pangan dan Gizi, Pusat Studi Pangan dan Gizi, Universitas Gadjah Mada (UGM).

Tepung ubi jalar ungu dibuat dari ubi jalar ungu yang dikupas, dicuci, diiris tipis, dikeringkan dalam cabinet dryer dengan suhu $50^{\circ} \mathrm{C}$ selama 8 jam, ditepungkan, dan diayak 80 mesh. Tepung jagung kuning dan tepung kacang tunggak dibuat dari jagung kuning pipilan kering dan kacang tunggak, yaitu masing-masing bahan direndam dengan air selama 10 jam, ditiriskan, dikeringkan dalam cabinet dryer dengan suhu $60^{\circ} \mathrm{C}$ selama 8 jam, ditepungkan, dan diayak 80 mesh. Masingmasing tepung dimasukkan dalam kantong plastik dan disimpan dalam refrigerator sampai saat akan diberikan kepada tikus.

Sebanyak 30 ekor tikus SD dimasukkan ke dalam kandang individual tertutup dengan ventilasi udara cukup serta temperatur udara pada suhu ruang. Masa adaptasi tikus dilakukan selama 7 hari. Dari awal sampai akhir penelitian, semua tikus diberi pakan diit standar dan air 


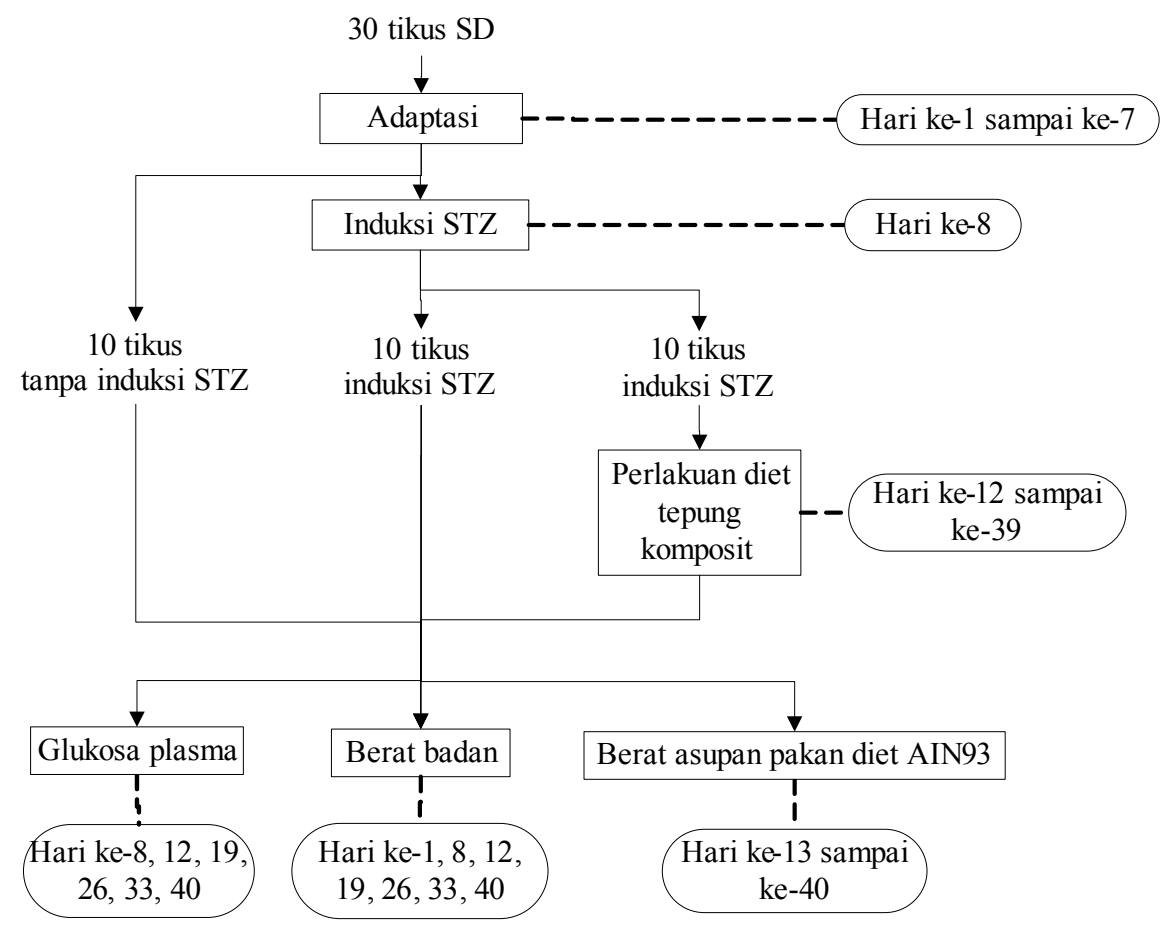

Gambar 1. Skema rancangan penelitian

minum diberikan secara ad libitum. Semua prosedur yang melibatkan hewan coba serta pemeliharaannya dilakukan dan dikondisikan berdasarkan kode etik yang dijalankan oleh pihak Laboratorium Pangan dan Gizi, Pusat Studi Pangan dan Gizi UGM.

STZ dilarutkan dalam larutan buffer sitrat $0,1 \mathrm{M}$ ( $\mathrm{pH} 4,5)$ kemudian diinduksi dengan single injection secara intraperitoneal (ke dalam rongga perut) dengan dosis $65 \mathrm{mg} / \mathrm{kg}$ berat badan (BB). Induksi STZ dilakukan pada 20 ekor tikus di hari ke-8. STZ akan memberikan hasil toksisitas pada sel $\beta$ pankreas selama 3 hari yang menyebabkan kadar glukosa darah meningkat melebihi kadar glukosa darah normal (di atas $200 \mathrm{mg} / \mathrm{dl}$ ). Selanjutnya, 20 tikus dibagi ke dalam 2 kelompok secara acak yaitu 10 ekor tikus DM dan 10 ekor tikus DM + tepung komposit.

Sampel tepung komposit (ubi jalar ungu, jagung kuning, dan kacang tunggak) diberikan secara force feeding yaitu dengan mencampurkan tepung komposit dan aquades dengan perbandingan 1:1, lalu diberikan secara oral menggunakan sonde cekok. Dosis yang diberikan yaitu 1,5 g/100 g BB, dengan perbandingan tepung ubi jalar ungu : tepung jagung kuning : tepung kacang tunggak $=5: 3: 2$. Berat rata-rata tikus adalah $200 \mathrm{~g}$ sehingga setiap tikus mendapatkan $3 \mathrm{~g}$ tepung komposit. Di dalam $3 \mathrm{~g}$ tepung komposit terdapat tepung kacang tunggak sebesar 0,6 g. Dosis tersebut merupakan modifikasi dari penelitian sebelumnya, yaitu perlakuan diit bubuk kacang tunggak selama 2 minggu dengan dosis $0,54 \mathrm{~g} / 200 \mathrm{~g}$ BB dapat mengakibatkan penurunan signifikan pada kadar glukosa darah yang lebih dari 200 $\mathrm{mg} / \mathrm{dl}$ menjadi 108,28 mg/dl (9).

Sampel darah tikus diambil lewat mata (plexus retroorbitalis) dengan menggunakan hematocrite tube setiap seminggu sekali yaitu pada hari ke- 8 , ke-12, ke19, ke-26, ke-33, dan ke-40, kemudian dilakukan analisis glukosa plasma darah dengan metode GOD-PAP (17). Demikian juga berat badan tikus yang ditimbang setiap seminggu sekali yaitu pada hari ke- 8 , ke-12, ke-19, ke26 , ke-33, dan ke-40. Sisa pakan standar tikus ditimbang setiap hari dimulai dari hari ke-12. Skema rancangan penelitian dapat dilihat pada Gambar 1. Data yang membentuk distribusi normal dianalisis menggunakan One Way Analysis of Variance (ANOVA) dan dilanjutkan dengan uji beda nyata menggunakan Duncan's Multiple Range Test (DMRT) pada taraf signifikansi 5\%. 
HASIL

\section{Kadar glukosa darah}

Pada Gambar 2, terlihat bahwa kelompok tikus yang mendapat diit tepung komposit (50\% tepung ubi jalar ungu, 30\% tepung jagung kuning, dan 20\% tepung kacang tunggak) mengalami penurunan kadar glukosa darah yang signifikan. Kadar glukosa darah yang awalnya $211,04 \mathrm{mg} / \mathrm{dl} \mathrm{menjadi} \mathrm{204,02} \mathrm{mg/dl} \mathrm{(3,33 \% )} \mathrm{pada} \mathrm{minggu}$ pertama; $176,52 \mathrm{mg} / \mathrm{dl}(16,36 \%)$ pada minggu kedua; $142,15 \mathrm{mg} / \mathrm{dl}(32,64 \%)$ pada minggu ketiga; dan 112,65 $\mathrm{mg} / \mathrm{dl}(46,62 \%)$ pada minggu keempat.

\section{Berat badan dan asupan pakan}

Tikus kelompok non-DM dari minggu ke-1 sampai ke-4, berat badannya mengalami peningkatan (Tabel 1) selama 40 hari penelitian yaitu sebesar 43,9 g (20,91\%). Tikus kelompok DM + tepung komposit yang sempat mengalami penurunan berat badan setelah diinduksi STZ, secara bertahap mengalami peningkatan berat badan sejak minggu ke-1 sampai ke-4 yaitu sebesar 17,2 g (8,21\%) setelah diberi asupan tepung komposit.

Ketiga kelompok tikus memiliki perubahan berat asupan pakan yang hampir sama dan tidak berbeda nyata (Tabel 2). Ini menunjukkan bahwa berat pakan yang dikonsumsi tikus akan berpengaruh pada berat badan tikus. Berat asupan pakan ini tidak termasuk dengan berat tepung komposit yang dikonsumsi. Tepung komposit yang pasti dikonsumsi tikus sebesar $3 \mathrm{~g} / 200 \mathrm{~g}$ BB tikus karena tepung dicampur dengan $3 \mathrm{ml}$ aquades, lalu dimasukkan dalam sonde untuk dikonsumsi oleh tikus secara oral.

\section{BAHASAN}

\section{Kadar glukosa darah}

Hasil penelitian ini menunjukkan bahwa terjadi penurunan glukosa plasma tikus diabetes induksi STZ setelah tikus diberi perlakuan diit tepung komposit

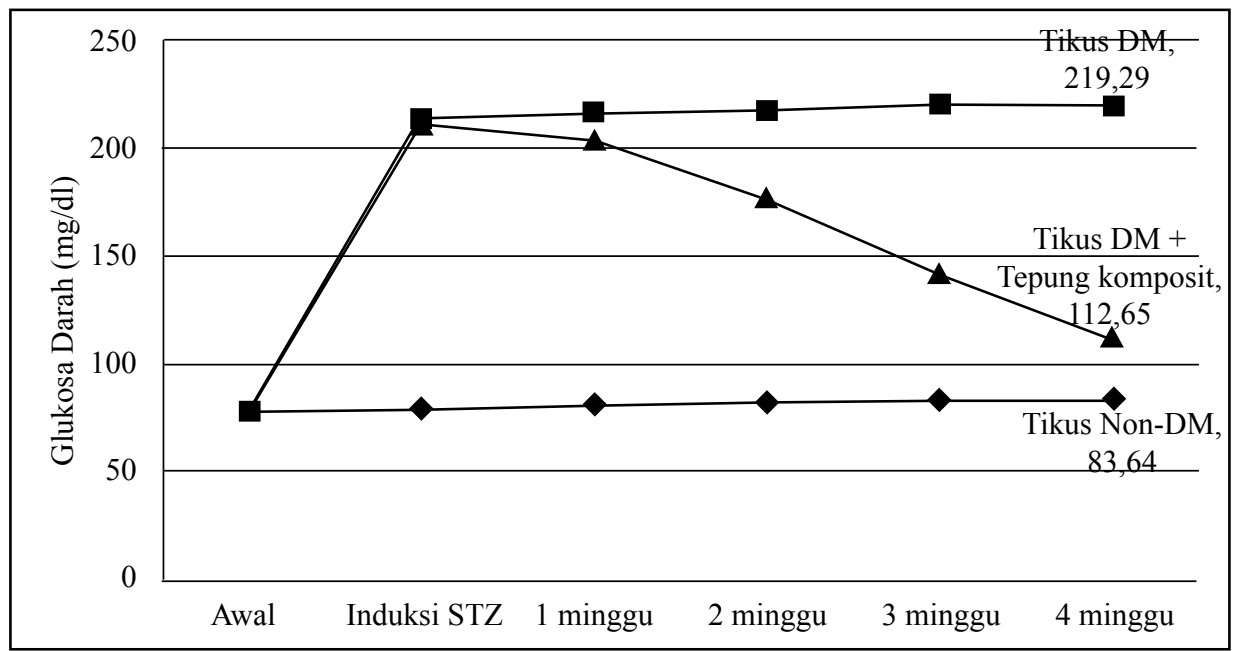

Gambar 2. Perubahan kadar glukosa darah (mg/dl) setelah diberikan diit tepung komposit selama 28 hari

Tabel 1. Berat badan tikus (g) selama penelitian

\begin{tabular}{lcccccc}
\hline \multirow{2}{*}{$\begin{array}{c}\text { Kelompok } \\
\text { tikus }\end{array}$} & \multirow{6}{c}{ Berat badan tikus (g) } \\
\cline { 2 - 7 } & \multirow{2}{*}{ Awal } & Induksi & \multicolumn{4}{c}{ Setelah perlakuan } \\
\cline { 4 - 7 } & & STZ & 1 minggu & 2 minggu & 3 minggu & 4 minggu \\
\hline Non-DM & $209,9^{\mathrm{a}}$ & $219,0^{\mathrm{b}}$ & $227,9^{\mathrm{c}}$ & $235,8^{\mathrm{c}}$ & $244,4^{\mathrm{c}}$ & $253,8^{\mathrm{c}}$ \\
DM & $213,7^{\mathrm{ab}}$ & $208,4^{\mathrm{a}}$ & $204,8^{\mathrm{a}}$ & $201,2^{\mathrm{a}}$ & $198,5^{\mathrm{a}}$ & $196,7^{\mathrm{a}}$ \\
DM + tepung komposit & $215,4^{\mathrm{b}}$ & $209,6^{\mathrm{a}}$ & $212,1^{\mathrm{b}}$ & $216,3^{\mathrm{b}}$ & $220,2^{\mathrm{b}}$ & $226,8^{\mathrm{b}}$ \\
\hline
\end{tabular}

Keterangan: superscript yang sama pada kolom yang sama menunjukkan tidak beda nyata $(\mathrm{p}<0,05)$ 
Carolina Sisca Djunaidi, dkk: Efek hipoglikemik tepung komposit (ubi jalar ungu, jagung kuning, dan kacang tunggak)

Tabel 2. Perbandingan berat asupan pakan dan berat badan tikus

\begin{tabular}{lcccccccc}
\hline \multirow{2}{*}{ Kelompok tikus } & \multicolumn{2}{c}{ Minggu ke-1 } & \multicolumn{2}{c}{ Minggu ke-2 } & \multicolumn{2}{c}{ Minggu ke-3 } & \multicolumn{2}{c}{ Minggu ke-4 } \\
\cline { 2 - 9 } & $\begin{array}{c}\text { BAP } \\
(\mathbf{g})\end{array}$ & $\begin{array}{c}\text { BB } \\
(\mathbf{g})\end{array}$ & $\begin{array}{c}\text { BAP } \\
(\mathbf{g})\end{array}$ & $\begin{array}{c}\text { BB } \\
(\mathbf{g})\end{array}$ & $\begin{array}{c}\text { BAP } \\
(\mathbf{g})\end{array}$ & $\begin{array}{c}\text { BB } \\
(\mathbf{g})\end{array}$ & $\begin{array}{c}\text { BAP } \\
(\mathbf{g})\end{array}$ & $\begin{array}{c}\text { BB } \\
(\mathbf{g})\end{array}$ \\
\hline Non-DM & $12,9^{\mathrm{a}}$ & $227,9^{\mathrm{c}}$ & $13,1^{\mathrm{a}}$ & $235,8^{\mathrm{c}}$ & $12,9^{\mathrm{a}}$ & $244,4^{\mathrm{c}}$ & $12,8^{\mathrm{a}}$ & $253,8^{\mathrm{c}}$ \\
DM & $12,9^{\mathrm{a}}$ & $204,8^{\mathrm{a}}$ & $13,0^{\mathrm{a}}$ & $201,2^{\mathrm{a}}$ & $13,1^{\mathrm{a}}$ & $198,5^{\mathrm{a}}$ & $12,7^{\mathrm{a}}$ & $196,7^{\mathrm{a}}$ \\
DM + tepung komposit & $12,8^{\mathrm{a}}$ & $212,1^{\mathrm{b}}$ & $12,9^{\mathrm{a}}$ & $216,3^{\mathrm{b}}$ & $12,9^{\mathrm{a}}$ & $220,2^{\mathrm{b}}$ & $12,8^{\mathrm{a}}$ & $226,8^{\mathrm{b}}$ \\
\hline
\end{tabular}

Keterangan: superscript yang sama pada kolom yang sama menunjukkan tidak beda nyata $(\mathrm{p}<0,05)$; BAP = berat asupan pakan diit standar AIN 1993; BB = berat badan

selama 28 hari. Tepung komposit (50\% tepung ubi jalar ungu, 30\% tepung jagung kuning, dan 20\% tepung kacang tunggak) yang digunakan sebanyak $3 \mathrm{~g} / 200 \mathrm{~g}$ berat badan tikus. Penurunan glukosa darah disebabkan oleh senyawa fungsional dan aktivitas antioksidan dalam tepung komposit. Kandungan kimiawi dalam $3 \mathrm{~g}$ tepung komposit secara teoretis dapat dihitung yaitu meliputi antosianin $(0,30 \mathrm{mg})$, serat pangan $(0,24 \mathrm{~g})$, protein $(0,29$ $\mathrm{g})$, total fenolik $(0,24 \mathrm{mg})$, dan terdapat aktivitas anti radikal 1,1-diphenyl-2-picrylhidrazyl (DPPH) sebesar $6,56 \%$ setiap mg fenol $(8,9,11,13)$.

Antosianin ubi jalar ungu didominasi oleh jenis peonidin glikosida dan sianidin. Struktur antosianin di dalamnya terdiri dari 2 pigmen non-acylated, 2 pigmen mono-acylated, dan 6 pigmen di-acylated (18). Antosianin yang terdapat dalam ubi jalar ungu lebih stabil dibandingkan dengan antosianin dari sumber pangan lainnya, disebabkan oleh adanya acylating agents berupa senyawa sinamat (caffeat, ferulat, dan p-hidroksibenzoat) sehingga dapat berperan aktif dalam menetralkan radikal bebas di dalam tubuh (19). Antosianin pada ubi jalar ungu mampu meningkatkan aktivitas penangkal radikal bebas dalam plasma darah tikus dan menghambat oksidasi plasma darah (20). Antosianin dapat berfungsi sebagai antioksidan, antimutagenik, antihipertensi, dan antihiperglisemik. Sifat antioksidatif tersebut karena kemampuan menyumbangkan hidrogen pada radikal bebas sehingga mencegah terbentuknya radikal bebas lebih lanjut (21). Antioksidan berfungsi menetralkan radikal bebas yang menyebabkan kerusakan dan kematian sel $\beta$ pankreas, serta melindungi sel $\beta$ pankreas agar tidak mengalami kerusakan. Melalui penurunan pembentukan radikal bebas, maka tubuh dapat meregenerasi sel yang rusak melalui mekanisme pembentukan sel baru sehingga jumlah sel $\beta$ pankreas berangsur-angsur menjadi normal (22).
Antioksidan di dalam kacang tunggak yang berupa senyawa fenol (p-hidroksibenzoat, 2,4-dimetoksibenzoat) dan turunan asam sinamat (p-kumarat, caffeat, sinamat, dan ferulat) dapat berperan sebagai antioksidan karena mampu menangkap radikal bebas DPPH (23). Senyawa fenolik dan aktivitas anti radikal DPPH pada kacang tunggak akan mempengaruhi kapasitas antioksidannya. Antioksidan dapat berperan dalam mencegah stres oksidatif lebih lanjut yang akan menghambat kerusakan jaringan seperti kerusakan sel $\beta$ pankreas. Kapasitas antioksidan dalam bubuk kacang tunggak juga dapat menurunkan kadar malondialdehide (MDA) plasma tikus DM yang diberi diit bubuk kacang tunggak selama $2 \mathrm{minggu}$, yang semula $11,20 \mathrm{mmol} / 1$ menjadi 2,36 $\mathrm{mmol} / \mathrm{l}(9)$.

Selain dari antioksidan, serat pangan dapat mengontrol dan menurunkan glukosa darah pada penderita diabetes. Serat pangan membuat larutan menjadi viskus sehingga meningkatkan viskositas pangan serta memperlambat absorbsi glukosa oleh usus halus. Molekul serat yang besar menutup pori-pori dinding mukosa usus sehingga efisiensi penyerapan glukosa turun (24). Hal ini mengakibatkan glukosa secara perlahan-lahan terserap ke dalam darah, yang akan menghambat kenaikan kadar glukosa darah secara drastis. Serat dapat membantu mempercepat pengeluaran sisa makanan melalui saluran pencernaan. Makanan yang mengandung serat akan memberikan rasa kenyang karena komposisi karbohidrat kompleksnya. Penelitian di Amerika menemukan bahwa konsumsi serat pangan mampu memperbaiki pengontrolan gula darah, menurunkan peningkatan insulin yang berlebihan di dalam darah, serta menurunkan kadar lemak darah. Hal ini berhubungan dengan kecepatan penyerapan glukosa masuk ke dalam aliran darah yang dikenal dengan 
indeks glikemik (IG). Serat pangan menunda penyerapan glukosa setelah makan sehingga menurunkan respon insulin terhadap masuknya karbohidrat (25). Protein juga berpotensi menurunkan kadar glukosa darah. Penurunan glukosa darah disebabkan protein yang masuk ke dalam pencernaan dapat mengurangi laju pergerakan makanan dalam usus halus sehingga memberikan rasa kenyang lebih lama dan memperlambat kenaikan glukosa darah (26).

\section{Berat badan dan asupan pakan}

Tikus kelompok non-DM dari minggu ke-1 sampai ke-4, berat badannya mengalami peningkatan selama 40 hari penelitian yaitu sebesar 43,9 gram $(20,91 \%)$. Demikian juga dengan tikus kelompok DM + tepung komposit yang secara bertahap mengalami peningkatan berat badan sejak minggu ke-1 sampai ke-4 yaitu sebesar 17,2 gram $(8,21 \%)$ setelah diberi asupan tepung komposit. Data tersebut menunjukkan bahwa tepung komposit yang diberikan mampu mempertahankan, bahkan meningkatkan berat badan. Hal ini disebabkan tepung ubi jalar ungu, tepung jagung kuning, dan tepung kacang tunggak yang digunakan merupakan sumber zat gizi (karbohidrat, protein, dan lemak) yang dapat meningkatkan berat badan (7-9). Tepung ubi jalar ungu dan kacang tunggak juga mengandung antioksidan dan serat pangan yang memberikan efek hipoglikemik yang mempengaruhi perbaikan berat badan berupa pertambahan berat badan tikus DM $(7,9,18)$.

Peningkatan berat badan tikus non-DM terjadi akibat tikus tidak menderita penyakit diabetes sehingga metabolisme di dalam tubuh tikus berjalan normal, yaitu energi yang digunakan oleh tikus diabetes berasal dari perombakan glukosa tanpa adanya perombakan lemak dan protein. Energi yang masuk melebihi energi yang dikeluarkan tikus, akibat dari sedikitnya aktivitas yang dilakukan tikus di dalam kandang. Hal tersebut menyebabkan ketidakseimbangan energi yang masuk dengan energi yang dikeluarkan (27).

Kelompok tikus DM dari minggu ke-1 sampai ke-4, berat badannya mengalami penurunan terus menerus (Tabel 1). Penurunan berat badan tikus DM disebabkan oleh beberapa faktor. Tikus DM tidak mampu menggunakan glukosa sebagai sumber energi akibat kekurangan insulin dan kerja insulin yang tidak maksimal. Walaupun dalam penelitian ini tidak dilakukan pengukuran hormon insulin, secara teori terbukti bahwa tikus DM mengalami kekurangan insulin karena induksi STZ merusak sel $\beta$ pankreas penghasil hormon insulin. Diabetes mellitus menyebabkan pengangkutan glukosa ke dalam sel menjadi terhambat dan membuat glukosa tidak dapat melalui proses glikolisis atau tidak dapat diubah menjadi glikogen (glikogenolisis). Akibatnya, proses penghasil energi berkurang sehingga lemak dan protein tubuh dipecah untuk menghasilkan energi $(28,29)$.

Penurunan berat badan tikus DM juga diakibatkan oleh poliuria. Ketika kadar glukosa melebihi batas glukosa dalam ginjal (karena glukosa yang tidak dapat diserap) maka timbul keadaan glukosuria (glukosa dalam urin). Ini menyebabkan perbedaan osmotik yang menimbulkan poliuria dan terjadi kehilangan energi karena jumlah kalori yang hilang dari glukosa urin. Penelitian di Turki melaporkan bahwa tikus SD non-DM mengonsumsi air sebanyak $16,49 \mathrm{ml} / 100 \mathrm{~g}$ berat badan sedangkan tikus DM mengonsumsi air sebanyak 52,03 $\mathrm{ml} / 100 \mathrm{~g}$ berat badan. Poliuria merangsang dehidrasi karena tubuh terus mengeluarkan air lewat urin yang menyebabkan penderita DM merasa haus secara berlebihan (polidipsia) $(28,30)$.

Hasil penelitian ini juga menunjukkan bahwa ketiga kelompok tikus memiliki perubahan berat asupan pakan yang hampir sama dan tidak berbeda nyata. Berat pakan yang dikonsumsi tikus akan berpengaruh pada berat badan tikus. Apabila diamati dari minggu ke-1 sampai ke-4, tikus non-DM berat badannya meningkat sedikit demi sedikit karena jumlah asupan pakan yang stabil dari minggu ke minggu, serta pakan standar yang diberikan mengandung asupan gizi yang diperlukan tikus berdasarkan AIN 1993. Meskipun berat asupan pakan tikus DM tidak berbeda nyata dengan berat asupan pakan tikus non-DM dan tikus DM + tepung komposit, tikus DM justru mengalami penurunan berat badan dari minggu ke minggu. Berat badan tikus DM seharusnya meningkat sedikit demi sedikit, seperti halnya yang terjadi pada berat badan tikus DM + tepung komposit karena berat asupan pakan ketiga kelompok tersebut tidak berbeda nyata. Namun, karena tikus DM tidak mendapatkan asupan diit tepung komposit maka tikus DM tetap menderita diabetes. Hal ini membuat tikus DM 
terus mengalami penurunan berat badan walaupun berat asupan pakannya tetap stabil seperti berat asupan pakan kelompok lainnya.

Di akhir minggu keempat, berat asupan pakan tikus non-DM dengan tikus DM + tepung komposit memiliki nilai yang hampir sama dan tidak berbeda nyata. Begitu pula pada berat badan kedua kelompok tikus tersebut, yang memiliki trend (pola) yang sama yaitu mengalami peningkatan berat badan sedikit demi sedikit. Tikus DM + tepung komposit seharusnya mengalami penurunan berat badan seperti yang terjadi pada tikus DM karena menderita diabetes. Namun, ternyata tikus DM + tepung komposit mengalami peningkatan berat badan sedikit demi sedikit karena mendapat asupan tambahan yaitu tepung komposit (ubi jalar ungu, jagung kuning, dan kacang tunggak). Tepung kacang tunggak mengandung antioksidan dan serat pangan (9) yang dapat memperbaiki berat badan tikus diabetes. Hal tersebut menunjukkan bahwa tepung komposit ini tidak memberikan efek negatif terhadap berat badan dan asupan pakan tikus selama penelitian.

\section{SIMPULAN DAN SARAN}

Tepung komposit (ubi jalar ungu, jagung kuning, dan kacang tunggak) dapat memberikan efek hipoglikemik pada tikus diabetes induksi STZ. Diit tepung komposit ini tidak memberikan pengaruh negatif ditinjau dari parameter berat badan dan asupan pakan tikus diabetes.

Perlu dilakukan penelitian lebih lanjut untuk mengetahui efek samping diit tepung komposit secara lebih detail dengan cara menguji kadar glukosa urin tikus, volume urin, dan jumlah feses tikus. Perlu dilakukan uji kadar antosianin, kadar total fenol, serat pangan larut, dan serat pangan tidak larut untuk mengetahui secara spesifik mengenai senyawa fungsional dalam tepung komposit. Penelitian secara in vitro juga perlu dilakukan untuk mengetahui faktor penentu dari tepung komposit yang mampu menurunkan kadar glukosa darah.

\section{UCAPAN TERIMA KASIH}

Penulis mengucapkan terima kasih kepada Indofood Riset Nugraha (IRN) 2013-2014 atas biaya penelitian yang telah diberikan. Penulis menyatakan bahwa tidak terdapat adanya conflict of interests.

\section{RUJUKAN}

1. Cahyono JBSB, editor. Gaya hidup dan penyakit modern. Yogyakarta: Kanisius; 2008.

2. Ariani, Nurlaeli, Haryono, Nurhayati. Studi potensi ubi jalar (Ipomoea batatas L.) lokal Tawangmangu dan olahannya berupa tepung sebagai salah satu alternatif sumber vitamin A. J Alchemy 2007;6(2):54-62.

3. Utomo JS, Antarlina SS. Peningkatan mutu tepung ubi jalar dan hasil olahannya. Jurnal Ilmu dan Teknologi Pangan 1997;2(1):44-9.

4. Antarlina SS, Utomo JS. Kue kering dari bahan tepung campuran jagung, gude, dan kedelai. Risalah Seminar Hasil Penelitian Tanaman Pangan. Malang: Balai Penelitian Tanaman Pangan; 1993.

5. Azman KI. Kue kering dari tepung komposit terigu-jagung dan ubi kayu. Sigma 2000;3(2):14-8.

6. Suarni. Pengembangan produk kue kering berbasis tepung jagung dalam rangka menunjang agroindustri. Prosiding Seminar Nasional Perhimpunan Teknik Pertanian Indonesia. Bandung: LIPI; 2005.

7. Antarlina SS. Peningkatan kandungan protein tepung ubijalar serta pengaruhnya terhadap kue yang dihasilkan. In: Winarto A, Widodo Y, Antarlina SS, Pudjosantosa H, Sumarno. Risalah Seminar Penerapan Teknologi Produksi dan Pascapanen Ubijalar Mendukung Agroindustri. Malang: Balittan; 1994.

8. Hardoko, Hendarto, Siregar. Pemanfaatan ubi jalar ungu (Ipomoea batatas L. Poir) sebagai pengganti sebagian tepung terigu dan sumber antioksidan pada roti tawar. Jurnal Teknologi dan Industri Pangan 2010;21(1):25-32.

9. Bolivar ACC, Luis CZ. Stability of anthocyanin-based aqueous extracts of Andean purple corn and red-fleshed sweetpotato compared to synthetic and natural colorants. J Food Chemistry 2004;86(1):69-77.

10. Atmaka W, Amanto BS. Kajian karakteristik fisikokimia tepung instan beberapa varietas jagung (Zea mays L.). Jurnal FP UNS Online [series online] 2010 [cited 2014 Jan 15];3(1):[24 screens]. Available from: URL: http://fp.uns. ac.id/jurnal/jurnal-58.html/

11. Suarni. Prospek pemanfaatan tepung jagung untuk kue kering (cookies). Jurnal Litbang Pertanian 2009;28(2):63-71.

12. Ariviani S, Handajani S, Affandi DR, Listyaningsih E. Pengembangan kacang tunggak (Vigna unguiculata) dan kacang gude (Cajanus cajan) sebagai minuman fungsional: efek hipoglikemik dan status antioksidan. Hibah Strategi Nasional [Laporan Penelitian dan Pengabdian kepada Masyarakat]. Surakarta: UNS; 2010.

13. Butt MS, Iqbal J, Naz A, Suleria HAR, Qayyum MMN, Saleem F, Jahangir MA. Effect of flour blending on bread characteristics. Internet Journal of Food Safety 2011;13:142-9. 
14. Szkuldelski T. The mechanism of alloxan and streptozotocin action in B cells of the rat pancreas. Physiol Res 2001;50(6):536-46.

15. Reeves PG, Nielsen FH, Fahey J. AIN-93 purified diets for laboratory rodents: final report of the American Institue of Nutrition ad Hoc Writing Committee on Reformulation of the AIN-76A Rodent Diet. J Nutr 1993;123:1939-51.

16. Ngatidjan. Metode laboratorium dalam toksikologi. Yogyakarta: Pusat Antar Universitas UGM; 1991.

17. Montilla EC, Hillebrand S, Winterhalter P. Anthocyanins in purple sweet potato (Ipomoea batatas L.) varieties. Fruit, Vegetable and Cereal Science and Biotechnology 2011;5(2):19-24.

18. Bolivar ACC, Luis CZ. Stability of anthocyanin-based aqueous extracts of andean purple corn and red-fleshed sweetpotato compared to synthetic and natural colorants. Food Chemistry 2004;86(1):69-77.

19. Suda I, Oki T, Masuda M, Kobayashi M, Nishiba Y, Furuta S. Physiological functionality of purple-fleshed sweet potatoes containing anthocyanins and their utilization in foods. JARQ 2003;37(3):167-73.

20. Lapornik B, Porsek M, Wondra A.G. Comparison of extracts prepared from plant by-products using different solvents and extraction time. J Food Engineering 2005;71(2):214-22.

21. Ghosh D, Konishi T. Anthocyanins and anthocyanin-rich extracts: role in diabetes and eye function. Asia Pac J Clin Nutr 2007;16(2):200-8.

22. Siddhuraju P, Becker K. The antioxidant and free radical scavenging activities of processed cowpea (Vigna unguiculata (L.) Walp.) seed extracts. Food Chemistry 2007;101(1):10-9.

23. Marlett JA, McBurney MI, Slavin JL. Position of the American Dietetic Association: health implications of dietary fiber. J Am Diet Assoc 2002;102(7):993-1000.

24. Bhat R, Karim AA. Exploring the nutritional potential of wild and underutiliized legumes. Comprehensive Reviews in Food Science and Food Safety 2009;8(4):305-31.

25. Gulliford MC, Bicknell EJ, Scarpello JH. Differential effect of protein and fat ingestion on blood glucose responses to high and low glycemix index carbohydrates in non insulin dependent DM. Am J Clin Nutr 1989;50(4):773-7.

26. Apriliyanti T. Kajian sifat fisikokimia dan sensori tepung ubi jalar ungu (Ipomoea batatas blackie) dengan variasi proses pengeringan [Skripsi]. Surakarta: UNS; 2010.

27. Jakicic JM, Rogers RJ. The importance of physical activity for losing weight, maintaining weight, and preventing weight gain. Research Digest President's Council on Fitness, Sports and Nutrition 2013;14(2).

28. Bayramoglu G, Senturk H, Bayramoglu A, Uyanoglu M, Colak S, Ozmen A, Kolankaya D. Carvacrol partially reverses symptoms of diabetes in STZ-induced diabetic rats. Cytotechnology 2014;66:251-7.

29. Tian HL, Wei LS, Xu ZX, Zhao RT, Jin DL, Gao JS. Correlations between blood glucose level and diabetes signs in streptozotocin-induced diabetic mice. Global J Pharmacol 2010;4(3):111-6.

30. Ghozali DS. Pengaruh diet tempe terhadap kesembuhan luka pada tikus diabetes yang diinduksi streptozotocin (STZ) [Skripsi]. Bogor: IPB; 2008. 